\title{
PENGARUH LAYANAN BIMBINGAN KELOMPOK DENGAN METODE ROLE PLAY TERHADAP PENINGKATAN KETERAMPILAN KOMUNIKASI ANTARPRIBADI PESERTA DIDIK UNTUK MENGHADAPI KONFLIK ORANGTUA - REMAJA (Studi Kuasi Eksperimen Terhadap Peserta Didik Kelas X di SMA Negeri 53 Jakarta Timur)
}

\author{
Dwi Fitria ${ }^{1}$ \\ Dra. Meithy Intan, R.L. M.Pd. ${ }^{2}$ \\ Susi Fitri, S.Pd., M.Si., Kons ${ }^{3}$
}

\begin{abstract}
Abstrak
Penelitian ini bertujuan meningkatkan keterampilan komunikasi antarpribadi peserta didik kelas X di SMA Negeri 53 Jakarta melalui layanan bimbingan kelompok dengan metode role play. Metode yang digunakan adalah kuasi ekperimen dengan pretest-posttest nonequivalent control group design. Sampel dalam penelitian ini mengggunakan purposive sampling, sehingga jumlah sampel dalam penelitian ini adalah duapuluh dua orang siswa kelas X SMA Negeri 53 Jakarta Timur. Pengumpulan data dilakukan dengan menggunakan instrumen pretest dan posttest yang dikembangkan oleh peneliti mengenai keterampilan komunikasi antarpribadi berdasarkan teori dari Joseph DeVito. Data tersebut dianalisis dengan menggunakan teknik Mann Whitney U Test. Hasil pengujian hipotesis menunjukkan bahwa nilai Asymp. Sig sebesar 0.000, yang berarti melalui hasil perhitungan tersebut maka diperoleh kesimpulan bahwa pada keterampilan komunikasi antarpribadi Sig < 0,05, artinya peningkatan keterampilan komunikasi antarpribadi siswa kelompok treatment lebih tinggi dibandingkan kelompok kontrol. Implikasi dari hasil penelitian ini adalah membantu meningkatkan keterampilan komunikasi antarpribadi siswa untuk menghadapi konflik orangtua - remaja kelas X di SMA Negeri 53 Jakarta Timur. Melalui dinamika kelompok, layanan bimbingan kelompok dapat memfasilitasi siswa untuk mengenal dan mengekspresikan perasaan diri dan orang lain, berpendapat serta membina hubungan dengan sesama anggota.
\end{abstract}

Kata kunci: bimbingan kelompok, komunikasi antarpribadi, konflik orangtua - remaja, role play

\footnotetext{
Mahasiswa Jurusan Bimbingan dan Konseling FIP UNJ, dwifitria.bk@gmail.com

Dosen Bimbingan dan Konseling FIP UNJ, meithy_intan@yahoo.com

3 Dosen Bimbingan dan Konseling FIP UNJ, fitri_penelitian@yahoo.com
} 


\section{Pendahuluan}

Hubungan remaja - orangtua adalah hubungan yang dekat dan hangat. Santrock mengatakan relasi yang erat dengan orangtua juga berperan penting bagi perkembangan remaja karena berfungsi sebagai model yang akan dibawa seumur hidup dan mempengaruhi relasi baru dikemudian hari (Santrock, 2007: 8). Santrockjuga menjelaskan bahwa saat remaja semakin mandiri, psikologis mereka akan lebih baik jika tetap mempertahankan kedekatan dengan orangtua (Santrock, 2007: 25) . Salah satu membina kedekatan dengan orangtua yaitu melalui komunikasi. Strategi ini dianggap paling efektif untuk mengubah sikap, pendapat atau perilaku manusia. Pada kenyataannya, masalah sering muncul di dalam sebuah keluarga karena terjadi hambatan dalam komunikasi. Komunikasi yang terhambat akan membuat segala tujuan gagal tercapai. Komunikasi menentukan seberapa besar kualitas hubungan antara orangtua - remaja. Adanya komunikasi, dapat mengontrol terjadinya konflik orangtua - remaja.

Hasil wawancara dan angket yang dilakukan di Sekolah Menengah Atas 53 Jakarta Timur menunjukkan bahwa peserta didik masih belum memiliki keterampilan komunikasi antarpribadi dalam menghadapi konflik orangtua - remaja. Padahal, jika dikaji secara teoritik menurut Hurlock rentang usia 14-16 tahun awal dimana masa remaja membangun hubungan yang baik dengan lingkungan sekitar, sehingga membutuhkan dukungan dari orang lain dalam menghadapi berbagai masalah (Hurlock, 2007: 206).

Oleh sebab itu layanan bimbingan kelompok merupakan suatu layanan esensial yang dibutuhkan oleh peserta didik. Layanan bimbingan kelompok yang dilakukan merupakan suatu bentuk pemberian informasi dari guru BK kepada peserta didik. Suatu pemberian informasi akan efektif jika didukung dengan metode yang menarik dan melibatkan peserta didik secara aktif. Layanan bimbingan kelompok akan membantu peserta didik atau individu untuk mampu mengenal dan menerima diri sendiri serta lingkungan sekitar mereka. Selain itu juga membantu mereka untuk mampu mengambil keputusan dan mewujudkan diri sebagai pribadi yang utuh sesuai peran dalam kehidupannya, salah satunya yaitu melalui metode role play.
Role Play memiliki keunggulan jika digunakan dalam layanan bimbingan kelompok karena mampu menyajikan suatu gambaran konflik yang akan langsung diperankan oleh peserta didik mengenai cara menghadapi konflik dengan orangtua. Melalui metode role play siswa dapat lebih memaknai materi strategi komunikasi antarpribadi, karena mereka harus menerjemahkan kembali definisi materi sekaligus memberikan contoh melalui peran yang dimainkan. Selain itu, peserta didik dapat membedakan serta memperkirakan keuntungan dan kerugian dari masing-masing penyelesaian konflik orangtua - remaja melalui komunikasi yang efektif. Remaja akan merasakan menjadi orang lain, merubah pandangannya melalui peran yang mereka lakukan. Sehingga, di tiap akhir pemberian layanan, siswa diharapkan akan mendapatkan pengalaman dan pemahaman baru mengenai kemampuan dalam berkomunikasi antarpribadi untuk menghadapi konflik orangtua - remaja.

\section{Kajian Teori \\ Konflik Orangtua - Remaja}

Shantz menjelaskan, konflik anak-orangtua yang terjadi selama masa remaja terbentuk sebagai kegiatan antar individu yang melibatkan perilaku yang saling bertentangan termasuk pertengkaran, ketidaksepakatan, dan argumen(Shantz, 1987: 1). Montemayor mengatakan, konflik orangtua-remaja tetap merupakan bidang penyelidikan yang penting karena merupakan hubungan yang konsisten antara interaksi keluarga yang mengalami konflik dan beberapa bentuk masalah-masalah internal dan ekternal dalam keluarga(Montemayor, 1986: 15-31) .

Rice dan Dolgin mengemukakan bahwa orangtua dan remaja saling tidak sepakat mengenai perilakuperilaku yang secara sosial dapat diterima oleh para remaja namun tidak untuk orangtua (Rice and Dolgin, 2005: 245). Rice dan Dolgin memaparkan lima area penyebab konflik orangtua - remaja yaitu social life, responsibility, school, family relationship, dan social convention. Pertama, Social Life. Area ini dapat menyebabkan konflik karena dekat dengan kehidupan remaja. Santrock menjelaskan, relasi yang baik di antara teman-teman sebaya dibutuhkan bagi perkembangan sosial yang normal di masa remaja(Santrock, 2007: 245). Penjelasan ini menun- 
jukkan bahwa dalam kaitannya dengan kehidupan sosial, remaja perlu berinteraksi dan menjalin relasi dengan teman sebaya. Pengaruh mengikuti keinginan teman-teman sebaya ini dapat berupa pengaruh positif maupun negatif. Pengaruh negatif inilah dapat menyebabkan konflik, contohnya adalah pergi keluar rumah bersama teman sebaya hingga lupa waktu. Kedua, Responsibilty. Smetana dan Asquith mengatakan masa remaja merupakan periode di mana remaja-remaja yang mandiri menantang usaha orangtua untuk menegaskan otoritas atas kegiatan dan perilaku remaja-remaja dirumah(Goodnow, 1988: 10). Pada masa ini remaja berani untuk menantang orangtua yang berusaha menegaskan posisi mereka sebagai orangtua atas remaja, sehingga terciptalah konflik. Ketiga, School. Eskilson menjelaskan, tekanan pada remaja untuk dapat berhasil di sekolah sangat besar dan menyebabkan menurunnya harga diri, perilaku menyimpang, serta perasaan gagal dalam mencapai target yang ditetapkan orangtua (Rice and Dolgin, 2005). Keempat, Family Relationship. Hubungan keluarga yang dimaksud adalah remaja dengan orangtua, saudara kandung, dan saudara lainnya. Collin menyatakan, orangtua dan remaja memiliki lebih banyak hal yang bisa di permasalahkan, harapan-harapan yang berbeda, daripada remaja dan teman sebaya(dalam Rice and Dolgin, 2005). Pendapat Rice dan Dolgin mengenai hubungan remaja dan saudara kandung, konflik terjadi karena adanya beberapa hal yang tidak sesuai seperti menggoda yang berlebihan, cara memanggil nama, menggunakan barang-barang milik saudara sehingga menganggu privasi salah satu pihak, dan lain-lain(Rice dan Dolgin, 2005: 247). Kelima, Social Convention. Santrock mengatakan, remaja tertarik pada obat-obatan karena dapat membantu mereka beradaptasi terhadap lingkungan yang selalu berubah (Santrock, 2007: 238). Menggunakan rokok, obat-obatan dan alkohol dapat mengurangi ketegangan dan frustasi.

\section{Komunikasi Antarpribadi}

Supratiknya mengatakan bahwa komunikasi antarpribadi adalah bentuk tingkah laku seseorang baik verbal ataupun nonverbal yang ditanggapi oleh orang lain(Supratiknya, 1995: 30). Adapun karakteristik efektifitas komunikasi antarpribadi, mengandung li- ma ciri yaitu (Joseph DeVito, 2007: 259-264) Pertama, keterbukaan (openess), yaitu sejauh mana individu memiliki keinginan untuk terbuka dengan orang lain dalam berinteraksi. Kedua, empati (empathy), yaitu kemampuan memproyeksikan diri kepada peranan orang lain maupun mencoba merasakan dalam cara yang sama dengan perasaan orang lain. Ketiga, dukungan (supportiveness), hubungan antar pribadi yang efektif adalah hubungan dimana terdapat sikap mendukung. Adanya dukungan dapat membantu seseorang lebih bersemangat dalam melakukan aktivitas serta meraih tujuan yang diinginkan. Keempat, positivitas (possitiveness), yaitu apabila menyatakan sikap secara positif terhadap diri maka situasi akan mendorong orang lain juga untuk merefleksikan perasaan positif. Kelima, kesetaraan (equality), adalah pengakuan bahwa kedua belah pihak memiliki kepentingan, kedua belah pihak sama-sama bernilai dan berharga, serta saling memerlukan.

\section{Role play}

Menurut Siberman teknik bermain peran atau yang ia sebut seni pemeranan, "merupakan metode belajar pengalaman (eksperiensial) yang sangat bermanfaat(Sibermen, 2011: 55). Metode ini bisa digunakan untuk menggairahkan diskusi, menyemarakkan suasana, mempraktikkan keterampilan, atau untuk merasakan atau mengalami. Menurut Bruce Joyce tujuan dari metode role play antara lain yaitu: 1) mengeksplorasikan perasaan siswa, 2) Mentransfer dan mewujudkan pandangan mengenai tingkah laku, nilai dan persepsi siswa, 3) Mengembangkan kemampuan pemecahan masalah dan tingkah laku, 4) Mengeksplorasikan materi pelajaran dengan cara yang berbeda (Bruce Joyce, 2009: 329). Adapun langkah-langkah dalam menggunakan metode role play, yaitu: 1) menghangatkan situasi kelas, 2) memilih partisipan, 3) mempersiapkan pentas, 4) menyiapkan pengamat, 5) memerankan, 6) diskusi dan evaluasi, 7) memerankan kembali, diskusi dan evaluasi (Bruce Joyce, 2007: 345-346).

\section{Metode Penelitian}

Penelitian ini bertujuan untuk mengetahui pengaruh bermain peran (role play) dalam layanan bimbingan kelompok terhadap keterampilan komunikasi antarpribadi untuk menghadapi konflik orangtua 
- remaja pada siswa kelas X SMA Negeri 53 Jakarta Timur. Penelitian ini dilakukan di SMA Negeri 53 Jakarta Timur, sejak bulan Januari sampai Desember 2014. Penelitian ini menggunakan pendekatan kuantitatif dengan metode kuasi eksperimen pretestposttest nonequivalent group design. Oleh sebab itu, penelitian ini akan melibatkan kelompok eksperimen sebagai kelompok yang akan mendapatkan perlakuan dan kelompok kontrol yang tidak mendapatkan perlakuan. Kedua kelompok akan mendapatkan pretest dan posttest yang bertujuan untuk mengetahui pengaruh variabel dependen $(\mathrm{X})$ yang tercermin dalam perbedaan variabel dependen khususnya $\mathrm{O}_{2}$ dan $\mathrm{O}_{4}$

Penelitian dilakukan sebanyak enam kali pertemuan dengan dua kali pertemuan untuk tes dan empat kali pertemuan untuk pelaksanaan eksperimen. Selama pelaksanaan eksperimen peneliti menggunakan metode role play. Populasi dalam penelian ini adalah seluruh peserta didik kelas X di SMA N 53 Jakarta yang berjumlah 180 orang. Sementara itu, teknik sampling yang digunakan dalam penelitian ini adalah purposive sampling dengan sampel berjumlah 22 orang, yaitu 11 orang peserta didik pada kelompok eksperimen dan 11 orang peserta didik pada kelompok kontrol.

Pada penelitian ini, pengukuran keterampilan komunikasi antarpribadi dilakukan dengan menggunakan instrumen yang dikembangkan oleh Josep DeVito pada tahun 2007, yang memiliki 5 aspek yaitu keterbukaan, empati, positivitas, dukungan dan kesetaraan.

Kualitas skor peningkatan keterampilan komunikasi pada sampel penelitian diketahui melalui pengujian gain skor menggunakan rumus sebagai berikut (Hepner, 2008):

Gain Skor = skor posttest - skorpretest

Pengaruh eksperimen terhadap sampel penelitian diketahui melalui pengolahan data dan analisis data menggunakan Mann Whitney U Test dengan menggunakan bantuan aplikasi SPSS versi 20.0.

\section{Hasil dan Pembahasan Hasil Penelitian}

Hasil pengujian hipotesis dengan menggunakan Mann Whitney U Test dengan aplikasi SPSS versi 20.0, diperoleh Asymp, Sig $=0.000$ dan diuji pada signifikansi alpha 0.05 .

Nilai Asymp. Sig $=0.000<$ nilai signifikansi $\alpha 0.05$

Berdasarkan data diatas dapat disimpulkan bahwa $\mathrm{H} 0$ ditolak dan $\mathrm{H} 1$ diterima, ini mengartikan bahwa terjadi peningkatan pada keterampilan komunikasi antarpribadi peserta didik setelah diberikan bimbingan kelompok dengan metode role play.

Perubahan dapat dilihat berdasarkan hasil dari pre-test dan post-test yang telah diberikan sebelum dan sesudah bimbingan kelompok dilakukan pada sebelas siswa SMA Negeri 53 Jakarta, didapatkan hasil sebagai berikut:

Tabel 1:

Bimbingan Kelompok, sebelum dan sesudah Test

\begin{tabular}{|c|l|c|c|c|c|}
\hline Kelompok & Kategorisasi & $\begin{array}{c}\text { Skor } \\
\text { Pre-Test }\end{array}$ & $\begin{array}{c}\text { Frekuensi } \\
\text { Pre-Test }\end{array}$ & $\begin{array}{c}\text { Skor } \\
\text { Post-Test }\end{array}$ & $\begin{array}{c}\text { Frekuensi } \\
\text { Post-Test }\end{array}$ \\
\hline \multirow{2}{*}{$\begin{array}{c}\text { Kelompok } \\
\text { Eksperimen }\end{array}$} & Rendah & $117-148$ & 11 & $125-141$ & - \\
\cline { 2 - 6 } & Sedang & $149-180$ & - & $142-158$ & 7 \\
\cline { 2 - 6 } & Tinggi & $181-212$ & - & $159-175$ & 4 \\
\hline \multirow{3}{*}{$\begin{array}{c}\text { Kelompok } \\
\text { Kontrol }\end{array}$} & Rendah & $117-148$ & 11 & $125-141$ & 11 \\
\cline { 2 - 6 } & Sedang & $149-180$ & - & $142-158$ & - \\
\cline { 2 - 6 } & Tinggi & $181-212$ & - & $159-175$ & - \\
\cline { 2 - 6 } & Jumlah & & 11 & & 11 \\
\hline
\end{tabular}

Berdasarkan tabel diatas, sebelum diberikannya bimbingan kelompok dengan metode role play tingkat keterampilan komunikasi antarpribadi siswa dalam menghadapi konflik orangtua - remaja, seluruh peserta didik berada pada kategori rendah. Setelah diberikannya bimbingan kelompok dengan metode role play, terjadi peningkatan pada rata skor keterampilan komunikasi antarpribadi peserta didik. Empat di antaranya berada di kategori tinggi, tujuh orang di kategori sedang dan tidak ada responden yang berada pada tingkat kategori rendah. Sedangkan pada kelompok kontrol, saat pretest dan posttest tetap berada pada kategori rendah, dengan kata lain tidak terjadi peningkatan. Skor rata-rata capaian siswa mengalami perubahan setelah diberikannya perlakuan, skor capaian sebelum dan sesudah perlakuan dapat dilihat dalam tabel berikut: 
Tabel 2:

Data skor pre-test dan post-test keterampilan komunikasi antarpribadi per individu

\begin{tabular}{|c|c|c|c|c|c|c|c|}
\hline \multirow{2}{*}{ Kelompok } & \multirow{2}{*}{ No } & \multirow{2}{*}{ Nama } & \multicolumn{2}{|c|}{ Pre-test } & \multicolumn{2}{|c|}{ Post-test } & \multirow{2}{*}{ Gain } \\
\hline & & & Skor & Kategori & Skor & Kategori & \\
\hline \multirow{11}{*}{$\begin{array}{c}\text { Kelompok } \\
\text { Eksperimen }\end{array}$} & 1 & $R$ & 120 & $R$ & 144 & $S$ & 24 \\
\hline & 2 & SN & 119 & $\mathrm{R}$ & 142 & $S$ & 23 \\
\hline & 3 & $\mathrm{~F}$ & 120 & $\mathrm{R}$ & 159 & $\mathrm{~T}$ & 39 \\
\hline & 4 & AAF & 121 & $R$ & 160 & $T$ & 39 \\
\hline & 5 & BW & 122 & $\mathrm{R}$ & 173 & $\mathrm{~T}$ & 51 \\
\hline & 6 & RY & 125 & $R$ & 161 & $T$ & 36 \\
\hline & 7 & $A R$ & 123 & $R$ & 143 & $S$ & 20 \\
\hline & 8 & EL & 116 & $\mathrm{R}$ & 144 & $S$ & 28 \\
\hline & 9 & JS & 118 & $\mathrm{R}$ & 147 & $S$ & 29 \\
\hline & 10 & PY & 121 & $\mathrm{R}$ & 142 & $S$ & 21 \\
\hline & 11 & TA & 117 & $\mathrm{R}$ & 143 & $S$ & 26 \\
\hline \multicolumn{3}{|c|}{ Rata-rata } & \multicolumn{2}{|c|}{120,11} & \multicolumn{2}{|c|}{150,72} & \\
\hline \multirow{11}{*}{$\begin{array}{c}\text { Kelompok } \\
\text { Kontrol }\end{array}$} & 1 & AM & 124 & $R$ & 130 & $R$ & 6 \\
\hline & 2 & SM & 124 & $\mathrm{R}$ & 136 & $\mathrm{R}$ & 12 \\
\hline & 3 & DAP & 121 & $\mathrm{R}$ & 128 & $\mathrm{R}$ & 7 \\
\hline & 4 & RNP & 118 & $\mathrm{R}$ & 127 & $\mathrm{R}$ & 9 \\
\hline & 5 & FD & 122 & $\mathrm{R}$ & 129 & $\mathrm{R}$ & 7 \\
\hline & 6 & RJ & 121 & $\mathrm{R}$ & 125 & $\mathrm{R}$ & 4 \\
\hline & 7 & RA & 124 & $R$ & 133 & $R$ & 9 \\
\hline & 8 & TW & 124 & $\mathrm{R}$ & 132 & $\mathrm{R}$ & 8 \\
\hline & 9 & $A K$ & 123 & $R$ & 126 & $R$ & 3 \\
\hline & 10 & IA & 124 & $\mathrm{R}$ & 129 & $\mathrm{R}$ & 5 \\
\hline & 11 & MRF & 121 & $R$ & 128 & $R$ & 7 \\
\hline \multicolumn{3}{|c|}{ Rata-rata } & 122,3 & & 129,3 & & \\
\hline
\end{tabular}

Skor capaian rata-rata sebelum diberikannya perlakuan adalah 120,11. Setelah diberikan, skor capaian rata-rata peserta didik meningkat menjadi 150,72. Hal ini mengindikasikan adanya pengaruh metode role play dalam meningkatkan keterampilan komunikasi antarpribadi siswa. Sedangkan pada kelompok kontrol, terjadi peningkatan dari 122,36 menjadi 129,36. Peningkatan yang terjadi pada kelompok kontrol lebih kecil dibandingkan pada kelompok eksperimen. Untuk memudahkan penggambaran deskripsi di atas, maka data tersebut dapat digambarkan dalam bentuk grafik sebagai berikut:

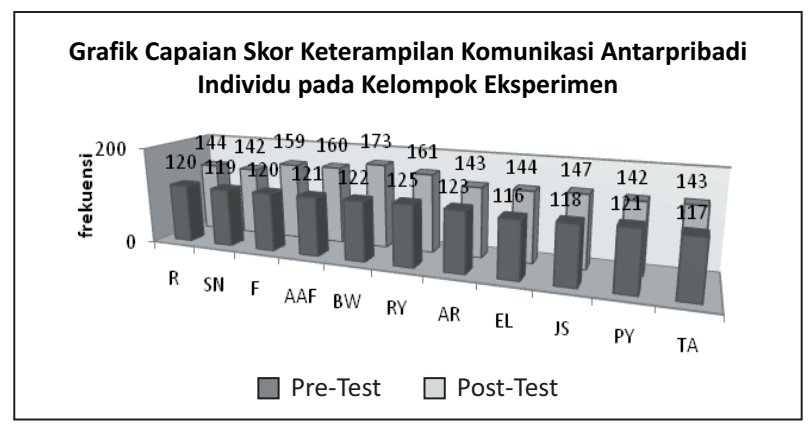

Gambar 1. Grafik skor rata-rata capaian keterampilan komunikasi antarpribadi siswa
Grafik Capaian Skor Keterampilan Komunikasi Antarpribadi Individu pada Kelompok kontrol

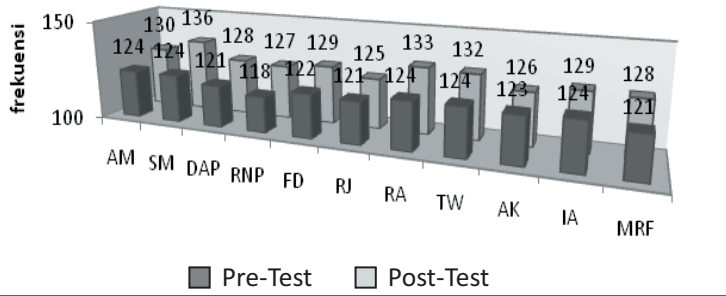

Gambar 2. Grafik skor rata-rata capaian keterampilan komunikasi antarpribadi siswa

Jika dilihat dari capaian yang didapatkan oleh peserta didik setelah melaksanakan layanan bimbingan kelompok dengan metode role play dan berdasarkan deskripsi di atas, peserta didik mulai mengembangkan penilaian positif terhadap orang lain, teruatama orangtuanya.

Ada beberapa faktor yang menyebabkan metode role play berpengaruh terhadap peningkatan keterampilan komunikasi antarpribadi. Faktor pertama, dalam role play anggota kelompok memiliki kesempatan untuk melihat masalahnya dari sudut padang yang berbeda. Selain itu anggota kelompok diberi kesempatan untuk mengidentifikasi sikap dan karakter dirinya dalam menghadapi konflik dengan orangtua. Dalam proses kegiatan yang telah dilakukan, anggota kelompok menganalisis hal-hal penting yang terjadi di dalam pementasan peran seperti cara berfikir remaja dalam menghadapi masalahnya dan emosi yang ditunjukkan saat remaja mengalami situasi atau kondisi tertentu ketika dihadapkan suatu masalah.

Faktor kedua adalah dalam proses kegiatan, anggota kelompok dapat berbagi pengalaman dalam menghadapi konflik dengan orangtua, sehingga anggota kelompok termotivasi untuk dapat menghadapi masalah yang terjadi dengan orangtua selama ini. Hal tersebut mereka ungkapkan ketika selesai pementasan peran dan menganalisis peran yang sudah mereka lakukan. Serta hasil kesimpulan dari angket evaluasi hasil yang sudah mereka kerjakan.

Faktor ketiga adalah karena role play membantu mereka dalam memahami dan menghayati posisinya atau posisi orang lain yang ia perankan, sehingga ia dapat merasakan hal positif atau negatif dari 
pola komunikasi antarpribadi yang diperankan. Sehingga remaja, dalam hal ini peserta didik bukan hanya sekedar tahu, tetapi paham dan mampu mengaplikasikannya dikehidupan mereka, karena memiliki gambaran yang mendalam melalui peran-peran yang mereka mainkan.

\section{Kesimpulan dan Saran}

Berdasarkan penelitian yang telah dilakukan, metode role play berpengaruh terhadap peningkatan keterampilan komunikasi antarpribadi dalam menghadapi konflik orangtua - remaja. Metode role play menjadi penanganan yang dapat meningkatkan keterampilan komunikasi antarpribadi karena dalam metode role play peserta didik dapat memiliki kesempatan untuk melihat masalahnya dari sudut pandang yang berbeda berdasarkan kasus yang dialami sehari-hari di dalam keluarga, khususnya dengan orangtua. Peserta didik diberi kesempatan untuk mengidentifikasi sikap dan sifat karakter utama, dan kejadian-kejadian penting di dalam kehidupan keluarga. Hal tersebut mengakibatkan individu memperoleh pemahaman diri di dalam berkomunikasi dengan orangtua, sehingga akan terlihat emosi yang ditunjukkan ketika melakukan komunikasi dengan orang lain dan merasakan jika menjadi orang lain, serta memiliki kemampuan untuk menghadapi permasalahan dan mengembangkan penilaian positif kepada orang lain, khususnya kepada orangtua. Role Play, dapat membuka wawasan peserta didik, membantu peserta didik dalam memahami orangtua sehingga menimalisir terjadinya konflik dengan orangtua, memperbaiki penilaian-penilaian negatif siswa terhadap orangtuanya, dan membelajarkan siswa untuk mengembangkan kemampuan penyelesaian masalah dalam kondisi atau lingkungan yang ada disekitarnya.

Bimbingan kelompok dengan metode role play merupakan salah satu bentuk alternatif pencegahan yang dapat diterapkan oleh guru bimbingan dan konseling di sekolah untuk memberikan informasi kepada siswa mengenai keterampilan komunikasi antarpribadi dalam menghadapi konflik orangtua remaja

\section{Referensi}

Allison, Barbara N. \& Jerelyn B. Schultz. 2004. ParentAdolescent Conflict in Earky Adolescence. Journal Adolescense. Libra Publishers, Inc.

Arikunto, Suharsimi. 2006. Prosedur Penelitian: Suatu Pendekatan Praktik. Jakarta : Rineka Cipta

Beaumont, L Sheery. (2004). Conflict : The Roles of Conversational Styles and Disgust Emotions. Journal of Language and Social Psycholog, 23, 338-368

Brooks, Jane B. 1991. The Process of Parenting. 3rd ed. Mountain View, CA: Mayfield Publishing Company.

DeVito. A. Yoseph. 2007. The Interpersonal Communication Book. USA : Pearson Education. Inc

Hurlock, Elizabeth B. 2007. Psikologi Perkembangan. Jakarta: Erlangga

Joyce, Bruce, Marsha Weil \& Emily Cathoun. (2009). Models of Teaching : Model-Model Pengajaran Edisi Delapan terjemahan Achmad Fawaid \& Ateilla Mirza. Yogyakarta: Pustaka Pelajar.

Montemayor, R. (1986). Family variation in parent-adolescent strom and stress. Journal of Adolescent Research, 1, 15-31.

Rice, F. Philip and Kim Gale Dolgin. 2005. The Adolescent: Development, Relationship, and Culture. 11th ed. United State of America: Pearson Education, Inc.

Santrock, John W. 2007. Remaja: Jilid 2 (Edisi 11). Diterjemahkan Oleh Benedictine Widyasinta. Jakarta: Erlangga

Silbermen, L. Melvin. 2011. Active Learning: 101 Cara Belajar Siswa Aktif. Bandung: Nusamedia.

Shantz, C. U., \& Hobart, C. J. (1989). Social conflict and development: Peers and siblings. In T. J. Berndt \& G. W. Ladd (Eds), Peer relationship in child development (pp. 71-94). New York: Wiley 